\title{
RECRUITMENT MODELS OF INDEPENDENT ELECTION ORGANIZING INSTITUTION IN YOGYAKARTA SPECIAL REGION
}

\author{
Suranto, Nasrullah, Tanto Nailam \\ Department of Government Science \\ Universitas Muhammadiyah Yogyakarta \\ Yogyakarta, Indonesia \\ suranto@umy.ac.id
}

\begin{abstract}
The quality of elections is highly determined by the election organizers which consist of Election Commission (Komisi Pemilihan Umum) and Election Supervision Agency (Badan Pengawas Pemilihan Umum) who must be independent and have high integrity. Therefore, permanent recruitment of election organizers must be perfect due to the significant impact on the quality of elections. The research aims to identify the issues of the recent recruitment model as well as formulate an ideal model of recruitment of permanent election organizers in Yogyakarta Special Region that guarantees the independence and integrity of the election organizers. The method applied is a qualitative research design using observation, depth interviews and focus group discussion for collecting data. The results show that the recruitment model of election organizers is regulated in three Laws, First, the Law No.12 of 2008 which shows the recruitment process still involved executive power; Second, the Law No. 15 of 2011 shows a better model; and in the Law No.7 of 2017 is quite ideal, which are indicated by the existence of public involvement in the recruitment process. However, there are several issues, such as: First, the difficulty to find an ideal candidates who have high integrity, high quality and comprehension of electoral skills; should be solved by an open recruitment using both of the CAT system and written documents to ensure that candidates for election management have good theoretical and practical skills; Second, the need of Provincial Election Committee and Provincial Election Supervisory Body involvement in selecting the candidates of Regency / City level election organizers; Third, the need of public awareness on the Election Organizing Institution as an independent and professional institution, so that political preferences can be suppressed.
\end{abstract}

Keywords: Election, Election Organizing Institution, Recruitment 


\section{INTRODUCTION}

The nature of elections in a democratic country is the embodiment of people's sovereignty which is manifested in the form of constitutional rights of citizens in a free and fair election in choosing both leaders and representatives who will manage and serve all levels of society at both the central and regional levels. One of the most important and strategic elements in realizing the free and fair elections is the existence of competent, independent and integrity organizers. Article 22E of the 1945 Constitution states that general elections are held by an electoral commission that is national, permanent and independent. The constitutional interpretation of the phrase "general election commission" in the Constitutional Court Decision Number 11 / PUUVIII / 2010 does not refer to a particular institution's name, but rather refers to the function of national, permanent and independent election management. Therefore the legislators in Law No.15 of 2011 concerning General Election Organizers and Law No.7 of 2017 concerning General Elections define Election Organizers as institutions that organize elections with a unique design consisting of the Election Commission (KPU), Election Supervisory Body (Bawaslu), and Election Organizing Honorary Council (DKPP) as a unit of the functions of the election administration. Article 6 of Law No.7 / 2017 states that KPU consists of National KPU, Provincial KPU, Regency/City KPU, District Election Committee, Village Election Committee, Election Committee Group and Overseas Committee Group.

The position of National KPU, Provincial KPU, Regency/City KPU is permanent. Meanwhile, the Article 89 of Law No.7/2017 also states that the Election Supervision is carried out by Bawaslu, which consists of National Bawaslu; Provincial Bawaslu; Regency/City Bawaslu; District Panwaslu; Village Panwaslu; Overseas Panwaslu; and Election Place Supervisor. The position of Bawaslu, Provincial Bawaslu, and Regency / City Bawaslu is permanent. In the local context, both the Provincial and the Regency/City Election Organizers have played significant role, so that the election's quality depends on the independence and integrity of the election organizers. Independent and impartial concept means to be free from other parties' intervention, which can reduce the ability of Election Organizers to perform such ideal elections (Jenedri, 2012: 109). In addition, to ensure that the honest and fair election could be implemented, the election organizers should have high integrity that is indicated by their positive qualities regarding the consistency of thoughts, words and actions so that they can be trusted and remain committed (Sansuri, 2016). The election organizers' independence and high integrity must be guaranteed since the recruitment process and during the execution of tasks (Jenedri, 2012: 109) which must be maintained so that the election organizer is free of external factors that could interfere their independence. The independence and integrity of the organizers is the key to organizing democratic elections (Nasef, 2014). The not neutral election organizers will have a direct impact on the collapse of the election administration quality. So that the House of Representatives establish Honorary Council of Election Organizers - DKPP - (Isra, 2017: 76). Despite the authoritative existence of DKPP, the facts show that there were 2,578 cases of 
alleged violations of the code of ethics to the DKPP involving 12,198 election organizers during 2012-2017. (http://dkpp.go.id/index). It means that there are some problems related to the independence and integrity of election administrators at all levels since the recruitment process. Therefore, it is necessary to formulate a new recruitment model that guarantees the independence and integrity of election administrators for both permanent and ad-hoc organizers. Based on the background, the research problem are as follows:

1. What are the advantages and disadvantages of the permanent election organizer recruitment model in Yogyakarta Special Region?

2. What is the ideal model for (permanent) election organizer recruitment in Yogyakarta Special Region which guarantees independence and integrity of election administrators?

\section{METHOD}

Type of the research is qualitative design, using library studies, observation, depth interviews and focus group discussions (FGD) for gathering data. To analyze data, this study used qualitative descriptive which can provide an clear exposure to the object of research. The qualitative descriptive analysis approach is carried out by treating objects based on certain categories, which aim to select relevant data, and then classified it juridical and systematically. Data analysis stages in research are namely (1) Facts organized and adjusted to the object of this study; (2) Systematized facts are described and explained according to the study object based on theory; (3) Facts that have been described are then evaluated. At this stage several activities were carried out such as collecting and reviewing secondary data and mapping the results of depth interviews with speakers and the results of focus group discussions (FGD) with stakeholders. (4) These activities are carried out to comprehend the focus of the research in depth and systematically.

\section{FINDING AND DISCUSSION}

\section{A. Advantages and Weaknesses of the General Election Organizers Recruitment System}

In a democratic country, elections have become the best mechanism in the process of changing positions of power. The philosophical spirit of Election is to provide equal opportunities for individuals to occupy desired positions while fulfilling specified qualifications. Elections also guarantee the rights of citizens to determine the leaders of their choice. Also through the General Election, the change of power which in the past was often traversed by means of violent or bloody coups, is now passed through constitutional means and competition with the rule of law as a reference standard for the implementation of elections. Elections also become a control tool for the quality of political leadership of a government. The people can give appreciation and punishment to 
ruling leaders to be able to continue or be replaced according to their performance when in power. Elections are a means of punishing negligent leaders of the people by not being elected again in elections. For leaders in power, elections are a means to gain legitimacy (DKPP, 2015: 10). The democratic general election standard states that free and fair elections can be achieved if there are legal instruments that regulate all the process of implementing elections; while being able to protect organizers, participants, candidates, voters, monitors, and citizens from fear, intimidation, violence, bribery, fraud, and various other fraudulent practices that will affect the election results. There are a number of internationally recognized standards, which are the benchmarks of democracy whether or not an election. This international standard is a minimum requirement for the legal framework to guarantee democratic elections. The indicators of these standards amount to 15 aspects, i.e: (1) legal framework preparation, (2) electoral system selection, (3) electoral district determination, (4) right to vote and be elected, (5) electoral administration body, (6) voter registration and voter list, (7) ballot paper access for political parties and candidates, (8) campaigns democratic elections, (9) access to media and freedom of expression, (10) financing and expenditure, (11) voting, (12) vote counting and recapitulation, (13) roles of party and candidate representatives, (14) election monitoring, compliance with the rule of law, and (15) enforcement of election regulations. The democratic elections is well implemented if the credibility of the election organizers (KPU, Bawaslu, and DKPP) is guaranteed. RH Taylor stated that elections are actually an absolute condition (conditio sine qua non) for the implementation of government based on the principle of representation, so democratic elections require a number of requirements, namely: (1) recognition of universal suffrage; (2) the freedom to form a shelter for the plurality of aspirations of the voting community; (3) the existence of a political recruitment mechanism for candidates for public representatives who are open; (4) there is freedom for voters to discuss and determine their choices; (5) the freedom for election participants to compete in a healthy manner; (6) there is an honest vote count; (7) bureaucratic neutrality; and, (8) the existence of an independent election organizing institution (Didik Supriyanto, 2007: 23). An ideal election can only be held by organizers who are not only capable, but also have high integrity. Election organizers work according to principles which are based on clear rules, measurable, and applicable. Their credibility is also determined by the public's perception of their performance in conducting a series of previous elections. The point is the aspects of leadership, integrity, independence, and electoral competency must be fulfilled. Referring to the International Institute for Democracy and Electoral Assistance standards, there are philosophical and normative foundations which are the main principles of the election organizers in holding elections, namely: (Ramlan Surbakti and Kris Nugroho, 2015: 17-18)

a. Independent: it is imperative for organizers to act independently in conducting elections. It is also indicated by the ability of the organizers to be free from any political interests and pressures.

b. Impartiality: Election organizers must perform both impartial attitudes and actions to election participants (either party or candidate). 
c. Integrity: Election organizers should have a personality and strong commitment to carry out their duties and authority to control all electoral processes in accordance with applicable legal rules and norms.

d. Transparency: Transparency is key to the governance of democratic elections, because it guaranteed election participants and the public are able to access information regarding the administration of elections both in terms of budget, policy and accountability of all stages of election administration.

e. Efficiency: Efficiency emphasizes the carefulness of the organizers in making right electoral planning, the right and efficient budget based on needs and priorities

f. Professionalism: election organizers must be expert figures and master electoral issues, recruited from candidates who have high qualifications as commissioners and prioritize shared interests to succeed in elections with integrity.

g. Service-mindedness: Election organizers are required to be able to provide services that prioritize all parties (parties, candidates, and the public) and prioritize work governance that can be accounted for from the legal aspect.

According to Ida Budhiaty, independence is the ability to maintain impartial behavior in a decision making as well as the ability to maintain behavior that is not easily perceived in favor. Integrity means the consistency among what is thought, said and done. The consistency of the election organizers include their independence, integrity and leadership will be tested after they are selected and also verified in practice with all its dynamics. Election implementation is the maturation process to test the independence and integrity of election administrators.

But the issue of leadership, independence, integrity, and professionalism in the administration of elections is not present, there is a long process that must be passed, especially related to the recruitment system and oversight of election organizers. The recruitment system for organizers of elections in this area must be directed to find election organizers who have good leadership, integrity, independence and electoral competence. Ramlan Surbakti and Kris Nugroho (2015: 15-16) stated that there are various models of election management membership selection referring to the methods used to select candidates for election management and those who are authorized to select them, namely:

1) Open recruitment through mass media.

The recruitment model for election organizers is conducted openly, namely by posting announcements in the mass media. Furthermore, interested candidates submit applications to independent teams to be selected for their qualifications based on their expertise and experience related to electoral. Some countries that use this open recruitment and selection model are Iraq, Namibia and South Africa.

2) Appointment by the government and submitted to parliament. 
The election organizer recruitment and selection model involves the role of the government. The plot is that the government submits the names of candidates in the electoral field, including legal experts to parliament for approval. Unlike the open recruitment and selection, this appointment model does not involve an independent team as the election organizer. An example of a country that applies the model of appointment of election organizers is Seirra Leone and Kenya. While in Ukraine, the appointment of election organizers is carried out through a different path, namely the parliament submits several names of candidates to the president (head of state) to choose several names. The names of candidates chosen by the president are returned to parliament for approval. This model gives parliamentary authority to establish and ratify electoral administration membership.

3) Recruitment and selection involving non-state institutions and legal experts. For the purpose of obtaining qualified candidates for election management, recruitment and selection involves legal experts, judges and election experts. The pattern is that there are public consultations from experts, such as involving the Judicial Commission in Botswana and in Guatemala the power of civil society is given a role in determining the nomination of election organizers.

4) Appointment of election organizers by state / government actors. The appointment of election organizers by state actors is also called unilateral appointment because it only involves the role of the state. Public roles such as lawyers and civil society forces are not involved. In this case the recruitment and selection of candidates is absolute in the authority of the state through the head of state who appoints it. Examples of countries that implement unilateral appointment models are India, Malaysia, Senegal and Zambia.

The recruitment model for election organizers in Yogyakarta has been contained in Law No.12 of 2008, Law No.15 of 2011, and Law No.7 of 2017. In Law No.12 of 2008, the recruitment process still involves executive power (Governors or Regents / Mayors), while Law No.15 of 2011 and Law No.7 of 2017 there is already a model of recruitment that has a measurable interactivity and process. The following are the advantages and disadvantages of the recruitment model contained in the regulations: 
Recruitment Models of Independent Election Organizing Instituation in Yogyakarta

Special Region

\begin{tabular}{|c|c|c|c|}
\hline Regulation & $\begin{array}{c}\text { Recruitment } \\
\text { Model }\end{array}$ & Advantages & $\begin{array}{c}\text { Disadvant } \\
\text { ages }\end{array}$ \\
\hline \begin{tabular}{|c|} 
Law No.12 of \\
2003
\end{tabular} & $\begin{array}{l}\text { Unilateral } \\
\text { Model }\end{array}$ & $\begin{array}{l}\text { Fast, effective and efficient, } \\
\text { Cheap } \\
\text { Government is able to choose } \\
\text { experts, and propose prefer } \\
\text { commissioners in accordance } \\
\text { with the wishes of the } \\
\text { government, and then submitted } \\
\text { to the National KPU or } \\
\text { Provincial KPU }\end{array}$ & $\begin{array}{l}\text { Less democratic } \\
\text { and transparent } \\
\text { Candidates are } \\
\text { potentially pro- } \\
\text { government } \\
\text { figures in power } \\
\text { (Governors, } \\
\text { Regents and } \\
\text { mayors) }\end{array}$ \\
\hline $\begin{array}{l}\text { Law No. } 15 \\
\text { of } 2011 \text { and } \\
\text { Law No. } 7 \text { of } \\
2017\end{array}$ & $\begin{array}{l}\text { Open } \\
\text { system } \\
\text { integration } \\
\text { and } \\
\text { involving } \\
\text { non-state } \\
\text { actors / } \\
\text { civil } \\
\text { society }\end{array}$ & $\begin{array}{l}\text { Involving the public } \\
\text { Transparency of selection and } \\
\text { parameters used } \\
\text { The public can provide a } \\
\text { candidate track record } \\
\text { - Democratic } \\
\text { - Transparency of the process } \\
\text { - Representing public aspirations }\end{array}$ & $\begin{array}{l}\text { Not all people } \\
\text { interested in } \\
\text { nominating } \\
\text { Psychological } \\
\text { barriers for fear } \\
\text { of failure } \\
\text { - A long selection } \\
\text { process } \\
\text { - The cost of a } \\
\text { large selection } \\
\text { - The possibility is } \\
\text { long because it } \\
\text { involves the } \\
\text { public } \\
\text { Too many } \\
\text { interests involved }\end{array}$ \\
\hline
\end{tabular}

\section{B. Ideal Model of Election Organizer Recruitment}

The recruitment system shows the quality of election organizers is determined by their leadership, integrity, independence and impartiality as well as professional at work. Based on the model, it can be infered that the model used to select election organizers in Yogyakarta today is a combination of open models and the involvement of non-state actors / civil society. This recruitment system is quite ideal, some of the advantages of this system are the existence of public involvement in the election organizer recruitment process, so that the results of recruitment can be accounted for (measurable accountability). Public involvement can be done both personally and institutionally (community organizations) in the form of proposing the best cadres from community organizations that have electoral competence, and of course can provide input on the track record of prospective organizers both with scientific perspectives, employment, 
social relations, and others. In addition, the current system is through the establishment of a Selection Team consisting of academics, professionals, and community leaders who have integrity.

However, in practice there are several weaknesses, which are:

\section{(1) Candidate's Capacity and Integrity}

An open recruitment system has implications for greater public involvement as well as socialization of recruitment will be easier, so that many parties are aware of the recruitment. However, the basic problem is the qualification of less competent candidates and many candidates who do have an interest in 'looking for job'. Requirements for candidates who must have electoral expertise have not been carried out consistently. The number of people who have competence in electoral governance in the district is indeed limited. Many candidates do not have adequate qualifications as candidates for KPU and Bawaslu commissioners at both the provincial and district / city levels. Based on the results of the FGD, it was found that not all Regency / City KPU members had experience and electoral expertise and many candidates did indeed register for employment. In fact, the issue of leadership, independence, integrity and professionalism of election organizers starts from the recruitment process, while election administrators (KPU and Bawaslu) who are professional, independent and have integrity are not only determined by a quality selection process, but the dominant factor lies in the quality of candidates who register as election organizer.

The different background of the candidates for the KPU and Bawaslu in Yogyakarta inhibits both KPU and Bawaslu commissioners to develop good understanding of electoral regulation. The ability of the KPU and Bawaslu commissioners to build this understanding is very important as legal and political legitimacy to conduct elections with integrity and legal certainty. The more diverse backgrounds of prospective KPU and Bawaslu members who register become an institutional challenge to build a recruitment system that is able to produce competent prospective commissioners. Therefore, it is necessary to improve the parameters used to select candidates to produce KPU and Bawaslu members who have high competence as election organizers. The specifications of candidates who must have scientific competence with electoral skills are needed to produce prospective commissioners who have sufficient expertise in electoral issues.

The requirement to be a member of the KPU basically involves five things, namely: First, having competence in the electoral system and electoral governance. Secondly, having independent or non-partisan independence or attitudes from election participants. Third, have personal integrity or conformity between attitudes and actions, honesty, and compliance with the law. Fourth, have effective leadership or the ability to convince, mobilize, and direct other people to act in accordance with the goals and programs set out on one side, and the ability to resist seduction, temptation, and pressure from other parties to take actions that are contrary to the objectives, programs, and 
applicable regulations. And fifth, have a body and be healthy in carrying out their duties and authority. But in the future, it needs to be added that considering that the Election Organizing institutions (especially Bawaslu) have the authority to settle disputes, it is idealized that half of the commissioners must have legal background.

\section{(2) Selection Committee}

The momentum of recruitment of election organizers is important to select adequate figures and empirically have competency and capable capacity. To recruit election organizers, the main responsibility lies on the Selection Committee, both in provincial or district / city level. The general requirements of the election organizer selection team determined by the KPU and Bawaslu, are as follows:

1) Has at least Strata $1(\mathrm{~S}-1)$ degree;

2) Age of 30 (thirty) years minimum;

3) Prohibited from running for candidates as members of the Provincial KPU and Regency / City KPU in all regions of Indonesia as well as for the Bawaslu.

4) Has a reputation, credibility, integrity and a good track record;

5) Understand material electoral, constitutional, and party;

6) Not become a member of a political party within a period of at least 5 (five) years commencing when registered as a candidate for the Selection Team;

7) Not currently serving as a member of the Provincial KPU and Regency / City KPU as well as Bawaslu

8) Does not have family relations including children, wife / husband, parents, siblings, in-laws, parents-in-law, daughter-in-law, partners with selection participants.

Meanwhile, the task of the Selection Committee is as follows:

1) Announce the registration of prospective election organizers;

2) Accept registration of candidates for election management members;

3) Conduct research on election administration;

4) Announce the results of the research on the administration of prospective election management members;

5) Make a written selection with the main material about knowledge and loyalty to the Pancasila, the 1945 Constitution of the Republic of Indonesia, the Unitary State of the Republic of Indonesia, and Bhinneka Tunggal Ika and knowledge about the election. Constitutional, and party (CAT system);

6) Do a series of psychological tests;

7) Announced through local mass media a list of names of provincial KPU candidate candidates who passed written selection and psychological tests to get community input and responses;

8) Conduct medical tests and interviews with the material for the General Election and conduct clarity on the responses and input of the community; 
9) Determine the name of the candidates for election organizer as many as 2 (two) times the number of candidates for election management members who end their term of office in a plenary meeting; and

10) Submit as many names as the candidates for election organizers 2 (two) times the number of election organizer candidates who end their term of office to the Central KPU / Bawaslu Center.

Some issues faced by the Selection Committee are: First, Due to some tasks have been partially carried out by electronic systems (CAT) and independent institution for psychological and health tests, Committee's tasks are in the form of accountability for CAT results, as well as psychological and health tests result. Therefore, the task is not heavy, so that the Committee only works fully to select candidates for election management at the interview stage. Ideally in the future, there should be a construction that every stage must have benchmarks relating to leadership, integrity, independence and impartiality and professionalism of the prospective organizers. For example in psychological and health tests, the chosen institution must be able to determine the standard of the questions relating to leadership, integrity, independence and impartiality and professionalism of the prospective organizers.

Second, to select candidates who have good leadership, integrity, independence and impartiality and good professionalism for election management depends on the quality of Selection Committee, who must have requirements above. But in fact in Yogyakarta, there is indeed recruitment that is open in the mass media for prospective Selection Committee, but some facts show that certain figures have been contacted before registration, and there are even academics who do not register but whose names are included in the Committee. On the other hand, there are members who lack understanding of electoral, constitutional, and party matters.

This means that there is a lack of clarity about the requirements and the recruitment process for the future, so that the benchmarks of the requirements and mechanisms for responsible recruitment must be emphasized. Ideally, a good selection process is a fixed and there is no opportunity for people who are not independent or do not meet the mastery requirements for electoral, constitutional, and party matters. Therefore, choosing the expected Selection Committee is not based on trial and error, likes or dislikes, or there are similarities with candidates. The Committee should pay more attention to the needs of the election organizers that are needed by the Central KPU and Bawaslu. The Committee shoud be the trigger to improve the quality of election organizers and also understand the functions and structure of election organizers from the central level to the region. In addition, The Committee should also prioritize not taking sides with political parties or regional officials who will take part in the process of 2018 local elections and 2019 elections. Election organizer candidates must be free from pressure, including the regional government and really has a vision and mission besides being experienced. The selection process should inhibit for recruiting inaccurately of people who are not independent. On the other hand, the work of Selection Committee must be monitored by the community due to 
its important role in recruiting potential people who conduct elections. The quality of the election organizers, depends on professionalism, independence and integrity of the Committee.

\section{(3) Selection Mechanism}

The written selection process currently uses the CAT (Computer Assessment Test) system, which the main material consists of knowledge and loyalty to Pancasila, the 1945 Constitution of the Republic of Indonesia, the Unitary State of the Republic of Indonesia, and Bhinneka Tunggal Ika and knowledge about elections, State Administration, and Party. In the CAT System, the questions are multiple choice, and participants only choose from the answers provided in the problem. The advantages of this CAT system, the perspective of CAT system accountability can be measured, because the selection participants can know firsthand the results / values of the tests conducted and participants can find out whether they will pass the next stage or not. According to the Indonesian Election Supervisory Board (Bawaslu) that the CAT system is believed to make the selection process free from corruption, collusion and nepotism, and can reduce the potential for question leakage, while increasing public confidence in the election administration institutions. Another advantage is the use of this CAT system also makes the budget issued by Bawaslu for the recruitment process more efficient (approximately 30\%) (https://nasional.kompas.com/read/2017/08/08/16351601/gunakansistem-cat- bawaslu-hemat-ongkos-rekrutmen-hingga-30-persen). In the electoral perspective, this CAT system only prioritizes the intellectual side of the participants, not on the basic understanding of elections and professionalism (including in matters of technical election). Moreover, the material contained in the exam questions does not touch on the practical issues of electoral affairs. Ida Budhiati's view that the CAT raises many problems, the fundamental problem is what is to be sought from the commissioners of the KPU and Bawaslu, whether it is only limited to the knowledge or skills of implementation. Quality election organizer systems cannot be measured by test material whose answers are "yes" or "no" or check point questions. The questions should be made that are able to explore the practical knowledge of electoralism, what is required is the ability of a commissioner to work professionally

In addition, the CAT system is difficult to reach people who have experience, because experienced people are usually busy, do not have time to read regulations, especially added in the CAT system there are questions related to constitutional knowledge. Selection with CAT is difficult to implement affirmation policies and is a system that is not friendly to women, female candidates must fight freely with male candidates, and if the percentage has not been met, the female candidate will fail. For example, passing the CAT graduation grade in the selection process 60 , but if a woman does not fulfill this value, it will definitely be declared a failure. To measure the professional ability of the election organizer, it must be realized by a test in the form of narrative questions rather than check points (which are more suitable for ASN selection). Narrative questions will make participants carry out a comprehensive 
elaboration on understanding regulations, theories and issues in electoral issues. In terms of transparency, the results of the written test can also be announced directly what the value is. This written system can accommodate affirmation policies for women and minority participants. In the future, the ideal system that can be done by combining the CAT system with a written system (essay), this is done to integrate intellectuality, integrity and professionalism of the selection participants. This combination is able to explore the potential and competency of candidates, while the acute problem of examinations can be done the same as the current system by announcing directly after the test and can show the test results to the selection participants. This combination can be done by balancing the percentage between the CAT system and the written examination system, for example CAT: $60 \%$, and written: $40 \%$. The combination of this system will benefit from the results of the selection, because participants who pass the selection must meet the criteria that have an understanding of electoral and constitutional theory, while the practical experience of holding elections is also a benchmark. For example in the Bawaslu selection process, in the selection process important Bawaslu is written selection considering Bawaslu also has the authority to adjudicate electoral cases. The competency issue of electoral dispute resolution cannot be measured by the CAT system.

\section{(4) Psychological and Health Tests}

Psychological testing is done in collaboration with partners (third parties) who are independent, psychological tests conducted so far are good models, because tests are carried out by competent parties and the results of the tests can be measured. Psychological tests in the recruitment of election organizers in Yogyakarta are a series of tests that aim to measure analytical skills, correct decision making, problem solving, ability to deal with pressure, and managerial and leadership abilities. The results of this test are in the form of a candidate ranking, so that the Selection Team can choose candidates who have high analytical skills, because they will be faced with decision making in a fast and appropriate time, have the ability to demand a lot of problems in a very short time, and has the ability to respond to pressures and interventions from various interests. Regarding the integrity issues of election administrators, there are certain questions to measure the high and low values of integrity possessed by each candidate. While health tests are also conducted in collaboration with partners (third parties) who are independent, medical tests conducted so far are a good model, because the tests are carried out by competent parties and the results of the tests can be measured. Health tests in the recruitment of election organizers in Yogyakarta are a series of tests that aim to measure the mental and physical health of prospective election organizers, so that the test material is in the form of psychiatric tests and physical health tests.

\section{(5) Interview Test}

The interview test is the authority of the selection team and is the last stage of the selection process carried out by the team. In the interview process, The Selection 
Committee will explore the integrity, independence, leadership and competence of prospective election organizers. In addition, the Committee will also explore the potential of prospective election organizers by questioning the contents of the papers made and questioning various kinds of insights related to the authority of the election organizers. In the interview stage, clarification is also made regarding the track record of election participants both in community life and within the scope of the institution where they worked previously. In the interview test will be detected related to leadership, independence, integrity, ethics, professionalism of the selection participants.

\section{(6) Final Decision}

The final determinant of the selection of Provincial KPU and Regency / City KPU members is the Central KPU, as well as for the Provincial and District / City Bawaslu member candidates the final determinant is Bawaslu. However, there are differences in election organizer selection, namely: in the selection of Regency / City KPU, Provincial KPU was not involved.

In contrast to the Regency / City Bawaslu recruitment, the Provincial Bawaslu is given the mandate to evaluate the selection results, but the final decision remains with the organizers of the central election. According to Abdullah Iskandar, this centralized system aims to form an independent Election Organizing Institution. This centralistic system is the result of an audience with the House of Representatives Commission II, Commission II explained that there were aspirations: many selection processes in the regions were intervened by regional heads, intervention of political parties, entrusted candidates, so that those who entered were not independent. That is the ratio built by the formulator of the law, so that to build an independent and clean organizing institution needs centralized selection. All in the center, for Bawaslu and the Provincial and Regency / City KPU, for example if the former bureaucracy enters the Election Organizing Institution, their relationship with the government is never released. Therefore Bawaslu was given the authority to form the Regency / City Election Supervisory Body, technically the Provincial Bawaslu was only given the mandate to assess, but the final decision remained in the Bawaslu RI and it was also possible that the Provincial Bawaslu was also entrusted.

The centralized implication of the institutional hierarchy, the provincial Bawaslu was involved with delegation to rank (ranking) through the fit and proper test, only the determination was made at the center. Although the ranking is not binding. (Interview, 16 August 2018). According to Ida Budhiaty, the centralistic selection model would have the potential for abuse of power and weaken hierarchical KPU and Bawaslu institutions. As a result, the compliance of the Regency / City KPU / Bawaslu is only to the KPU / Bawaslu of the Republic of Indonesia, even though its coverage is limited.

While because the position of provincial level Election Organizers does not have the authority to choose and determine, there will be non-compliance with the institution. (Interview, 15 August 2018). Ideally in the future, central level election organizers have the authority to elect and determine candidates for provincial election administrators, 
while provincial level election organizers have the authority to elect and determine candidates for district / city level election organizers, and so on up to the lower levels.

\section{(7) Interventions and Political Preferences}

The problem of recruitment that has been universal in our country is that there are too many non-professional considerations, there is a tribal approach, an organizational approach, a majority - minority group that overrides aspects of capacity and integrity. In fact, political preference does occur, but it is difficult to map both in determining the timsel and the election organizer. This determination of Committee which is not transparent and responsible is the entrance for the Commitee to determine who are community leaders, academics, and professionals whose vision and mission, as well as their organizations are in accordance with the commissioners at the KPU and Bawaslu Center. But this preference politics cannot be avoided in the recruitment process, given the public involvement in its constituency. According to Refly Harun, the fundamental problem in the current selection system is preference politics that influence or at least intervene in the selection process of the Provincial KPU / Bawaslu as well as at the District / City level. Selected candidates are cadres from certain community organizations, not based on the integrity and professionalism of the selection participants. This preference politics will disrupt the Indonesian democratic system that has been built with the spirit of reform, and will disrupt if the Election Organizing Institution is considered the same as the representative institution (interview, August 14, 2018). In the future, of course, there is political awareness from certain parties, both community organizations, to equate the perception that election organizers are not political institutions that convey the aspirations of organizations or communities. However, community organizations are important to prepare the best cadres to participate in the contest fairly, so that the elected election organizer candidates are people who have good leadership, integrity, independence and impartiality, and professionals in carrying out the mandate of popular democracy. 


\section{CONCLUSION}

The recruitment model for election organizers in Yogyakarta has been contained in Law No.12 of 2008, Law No.15 of 2011, and Law No.7 of 2017. In Law No.12 of 2008, the recruitment process still involving executive power (Governor or Regent / Mayor), while Law No.15 of 2011 and Law No.7 of 2017 there are already good recruitment models and measurable processes. The recruitment system contained in Law No.7 of 2017 is quite ideal, some of the advantages of this system are the existence of public involvement in the election organizer recruitment process, so that the results of recruitment can be accounted for (measurable accountability). Public involvement can be done both personally and institutions (community organizations) both in the form of proposals for the best cadres from community organizations that have electoral competency, and of course can provide input on the track record of prospective organizers both with scientific perspectives, work, social relations and others. In addition, the current system is through the establishment of a Selection Team consisting of academics, professionals, and community leaders who have integrity. However, in practice there are several weaknesses and can be improved in the future, namely: finding candidates with integrity, quality and good understanding of electoral skills; Selection Committee must be open recruitment, a combination of the CAT system with written to ensure candidates for election management have good theoretical and practical skills; involvement of the Provincial KPU and Provincial Election Supervisory Body to select and determine candidates for the Regency / City level election organizers; increasing public awareness that the Election Organizing Institution is an independent and professional institution, so that political preferences can be suppressed. 


\section{REFERENCE}

Mukthie Fadjar, -Pemilu yang Demokratis dan Berkualitas: Penyelesaian Hukum Pelanggaran Pemilu dan PHPU, Jurnal Konstitusi, Volume 6, Nomor 1, April 2009

Muhammad Asrun, 2004, Krisis Peradilan: Mahkamah Agung di Bawah Suharto, Andi Subri, dalam -Pemilihan Umum Tahun 2014: Pemilih Rasional dan Pemilih

Irrasionall, Jurnal Legislasi Indonesia, Volume 9 No.4 Desember 2013.

Bisariyadi, dkk., dalam -Komparasi Mekanisme Penyelesaian Sengketa Pemilu di Beberapa Negara Penganut Paham Demokrasi Konstitusional, Jurnal Konstitusi Volume 9, Nomor 3, September 2012

Dahlan Thaib dan Nillmatul Huda, 1992, Pemilu dan Lembaga Perwakilan Dalam Ketatanegaraan Indonesia, Hukum Tata Negara, Fakultas Hukum Universitas Islam Indonesia, Yogyakarta

David Bentham dan Kevin Boyle, 2000, Demokrasi, Kanisius, Yogyakarta.

Didik Supriyanto, 2007, Menjaga Independensi Penyelenggara Pemilu, USAID, DRSP, Perludem.

DKPP, Penyelenggaraan Pemilu di Dunia

Fitra Arsil, -Mencegah Pemilihan Umum Menjadi Alat Penguasal, Jurnal Legislasi Indonesia Vol. 9 No. 4 Desember 2012

Hamdan Zoelva, dalam -Problematika Penyelesaian Sengketa Hasil Pemilukada oleh Mahkamah Konstitusill, Jurnal Konstitusi, Volume 10, Nomor 3, September 2013

Janedjri M. Gaffar, 2012, Politik Hukum Pemilu, Jakarta, Konstitusi Press.

Jimly Asshidiqqie, dalam -Partai Politik dan Pemilihan Umum Sebagai Instrumen Demokrasill, Jurnal Konstitusi, Volume 3, Nomor 4, Desember 2006

Lusy Liany, -Kewenangan DPR dalam Seleksi Komisioner KPUl, Adil: Jurnal Hukum, Volume 7 Tahun 1, 2016.

M.Imam Nasef, -Studi Kritis Mengenai Kewenangan Dewan Kehormatan Penyelenggara Pemilu dalam Mengawal Electoral Integrity di Indonesiall, Jurnal Hukum IUS QUIA IUSTUM NO. 3 VOL. 21 JULI 2014: $378-401$.

Moh. Kusnardi dan Harmaily Ibrahim,1983, Hukum Tata Negara Indonesia, Pusat Studi Hukum Tata Negara, Fakultas Hukum Universitas Indonesia, Jakarta

Moh.Mahfud, MD., 1999, Pergulatan Politik dan Hukum, Gama Media, Yogyakarta Mukti Fajar dan Yulianto Achmad, 2005, Dualisme Penelitian Hukum Normatif dan

Empiris, Pustaka Pelajar, Yogyakarta, hlm.187-191

Ni‘matul Huda dan Imam Nasef, 2017, Penataan Demokrasi \& Pemilu di Indonesia Pasca Reformasi, Jakarta, Kencana. 
Ramlan Surbakti dan Kris Nugroho, 2015, Studi tentang Desain Kelembagaan Pemilu yang Efektif, Kemiteraan Partnership, Jakarta

Rozali Abdullah, 2009, Mewujudkan Pemilu yang Berkualitas, Jakarta, PT Rajagrafindo Persada.

Saldi Isra, 2017, Pemilu dan Pemulihan Kedaulatan Rakyat, Jakarta, Themis Publishing

Tatang Sudrajat, -Evaluasi Kebijakan Rekrutmen Anggota KPU Kabupaten/Kota dalam Penyelenggaraan Pemilu Tahun 2014 di Jawa Baratll, Jurnal Ilmu Administrasi, Volume XI Nomor 1, April 2014

Tim ICCE UIN Jakarta, 2003, Demokrasi, Hak Asasi Manusia, dan Masyarakat Madani, ICCE UIN Syarif Hidayatullah dan Kencana, Jakarta.

Veri Junaidi, dalam -Menata Sistem Penegakan Hukum Pemilu Demokratis Tinjauan Kewenangan MK atas Penyelesaian Perselisihan Hasil Pemilu (PHPU), Jurnal Konstitusi Volume 6, Nomor 3, September 2009

Yulia Sari, -Model Seleksi Anggota KPU Kabupaten/Kota di Provinsi Sumatera Barat untuk Penyelenggara Pemilu yang Beretikall, Proceeding Seminar Nasional II Fakultas Ilmu Sosial dan Ilmu Politik Universitas Andalas, Padang, 28-29 September 2016. 